\title{
Principal-agent Theory and Its Application to Administrative Management
}

\author{
Xueqing Chen \\ Institute of Tropical Agriculture and Forestry, Hainan University, Danzhou 571737, China
}

18120250688@163.com

Keywords: principal-agent theory; administrative management; entrusted subjects

\begin{abstract}
The principal-agent theory plays an important role in standardizing government behaviors and ensuring proper exercise of the administrative power. Recent years have witnessed increasing application of the principal-agent theory to fields, notably politics and society, and the connection between the principal-agent theory and these fields has been increasingly cemented. Against the backdrop, this paper briefly introduces the principal-agent theory, and expounds on application strategies of the principal-agent theory in administrative management. It is hoped that this research can bring inspirations to personnel in relevant fields.
\end{abstract}

\section{Introduction}

Emerging in the 1960s, the principal-agent theory has been regarded as one of the major development achievements of the contract theory over the past 30 years. After years of development, the achievement has been integrated into multiple fields, including economy, society and politics. In order to better apply the principal-agent theory to the field of administrative management, this paper studies the principal-agent theory and feasibility of its application to administrative management.

\section{Overview of the principal-agent theory}

\subsection{Overview}

The principal-agent theory mainly studies a contract relationship under the information asymmetry condition. The contract relationship can also be regarded as entrustment of the agent to make some decisions on behalf of the principal. Table 1 represents the prerequisites or hypotheses of the principal-agent theory. These hypotheses have a close connection with the agency cost and the non-efficiency loss.

Table 1. Hypotheses of the principal-agent theory

\begin{tabular}{c}
\hline Hypotheses of the principal-agent theory of the principal-agent theory \\
Separation between ownership and management \\
Conflicts between the utility objective of the principal and the agent \\
Existence of risks and uncertainties
\end{tabular}

\subsection{Necessity}

China is in a critical period of economic and social transformation. To get adapted to changes of the world politics and economic development during the period, the Chinese government should not ignore analysis of the operation mechanism functioning within it. The two multi-layer entrustment systems constitute the basic structure of China's administrative governability. The loop system thus formed is excessively influenced by the layers, which can easily result in weakening of supervision and incentive effects. This problem in essence can be interpreted as the agent's loss of control of its behaviors. Alienation of rights, generalization of functions, increase of corruption and low efficiency - all these are specific reflections of problems of the kind. In order to decrease the occurrence of problems of the kind, it is highly necessary to apply the principal-agent theory to 
administrative management [1].

\section{Strategies of applying the principal-agent theory to administrative management}

Combining the development status of China's administrative management, this paper puts forward strategies of applying the principal-agent theory to administrative management in three aspects. It is hoped that these strategies can offer some implications for personnel in relevant fields.

\subsection{Legal support}

Application of the principal-agent theory to administrative management cannot be separated from adequate legal support. The legal basis justifying such application to be included in laws should be provided. Currently, China's Administrative License Law, Administrative Penalties Law, and Interpretation of Implementing the Administrative Procedures Law differ in terms of their stipulations on application of the principal-agent theory to administrative management. This will easily give rise to disagreements during the application process. Identification of the legitimate subjects and administrative subjects falls under the scope of government responsibilities. According to the definition of the principal-agent theory, it can be found that administrative management departments are more suitable to act as implementers of the entrustment decision-making right. However, during the application of the principal-agent theory to administrative management, there are two layers of principal-agent relationships, including legislative subjects and the administrative subjects, administrative subjects and administrative agents. The ever-changing and complex law enforcement scenarios often restricts administrative entrustment from fully playing its role. "ex post facto legislation" is the best case in point of problems of the kind.

During the survey process, the author finds out that it is still controversy as to whether there should be legal standards regulating application of the principal-agent theory to China's administrative management. Interpretation of Implementing the Administrative Procedures Law stipulates, "administrative entrustment is legitimately valid even if there is no legal basis". Currently, the Chinese government is faced with continuous changes of the transitional period. Legislation cannot exactly predict potential theoretical problems arising from application of administrative entrustment. Because of lack of legislation for specific problems, the administrative departments of the lower level have been asking for the administrative enforcement right from the administrative departments of the upper level. As an example, Table 2 shows Reply of the Ministry of Environmental Protection on Entrusting the Hubei Provincial Environmental Protection Bureau to Issue Radiation Safety License 2010 and Reply on Agreeing Entrustment of Environmental Protection Inspection Institutions for Functioning Motor Vehicles by the Liaoning Provincial Government 2015. The author thinks that application of the principal-agent theory to administrative management should focus on legal standardization of administrative entrustment and qualifications. Only in this way can legal support promote application of the principal-agent theory to the utmost extent.

Table 2. Examples of “claiming” for the administrative enforcement right

\begin{tabular}{cc}
\hline Examples & Content \\
\hline $\begin{array}{c}\text { Reply of the Ministry of Environmental } \\
\text { Protection on Entrusting the Hubei Provincial } \\
\text { Environmental Protection Bureau to Issue } \\
\text { Radiation Safety License 2010 }\end{array}$ & $\begin{array}{c}\text { Entrustment of the motor vehicle } \\
\text { environmental protection inspection } \\
\text { institution qualifications }\end{array}$ \\
$\begin{array}{c}\text { Reply on Agreeing Entrustment of } \\
\text { Environmental Protection Inspection }\end{array}$ & $\begin{array}{c}\text { Entrustment of issuing the radiation } \\
\text { safety license }\end{array}$ \\
$\begin{array}{c}\text { Institutions for Functioning Motor Vehicles by } \\
\text { the Liaoning Provincial Government 2015 }\end{array}$ & \\
\hline
\end{tabular}




\subsection{Selection of entrusted subjects}

The scope of entrusted subjects is also an issue requiring immediate solution during the application of the principal-agent theory to administrative management. As one observes in Table 3, entrustment items can directly influence the scope of entrusted subjects. In recent years, scholars both at home and abroad have been discussing whether individuals can become entrusted subjects of power-related affairs. For a long time, private business management and enterprise management have been regarded as typical public administrative responsibilities. This excludes individuals from the administrative management entrustment and goes against the original intention of the principal-agent theory. In order to realize efficiency pursuit and unification of the administrative democracy, this paper suggests that the application scope of the principal-agent theory should not be confined to the scope of the entrusted subjects. Considering that China has long been a critical transitional period of economic and social development and that the major entrusted subjects in the traditional principal-agent theory are administrative departments and public institutions, this paper suggests that the government should take the application value of the traditional principal-agent theory seriously, and promote the functional transformation through continuous improvement of marketization and segmentation of social labor distribution. Meanwhile, the administrative activities should be divided into different links. In other words, the entrusted subjects can be identified based on characteristics of different links. For example, administrative behaviors, before decision of administrative penalties is made, mainly include inspection, evidence collection and authentication. These administrative behaviors can be entrusted to qualified individuals through labor distribution. Of special note is that the government should clarify the qualifications of individuals before entrustment. Only in this way can the legitimate enforcement qualification of entrusted subjects will be freed from the influence of the application of the principal-agent theory. All in all, selection of the entrusted subjects should focus on the acquisition and review of personnel's law enforcement qualifications [2].

Table 3. Influence of entrustment items on the scope of entrusted subjects

\begin{tabular}{ccc}
\hline Entrustment items & Entrusted subjects & Entrusted content \\
\hline Administrative penalties & $\begin{array}{c}\text { Institutional organizations } \\
\text { legitimately set up to manage } \\
\text { public affairs }\end{array}$ & $\begin{array}{c}\text { Implementation of } \\
\text { administrative penalties }\end{array}$ \\
Administrative license & $\begin{array}{c}\text { Other administrative } \\
\text { departments }\end{array}$ & $\begin{array}{c}\text { Implementation of } \\
\text { administrative license }\end{array}$ \\
Administrative collection & $\begin{array}{c}\text { Organizations and } \\
\text { personnel }\end{array}$ & $\begin{array}{c}\text { Collection of scattering } \\
\text { taxes or taxes paid from one } \\
\text { place to the other }\end{array}$ \\
Administrative & No entrustment allowed \\
\hline
\end{tabular}

\subsection{Clarification of the scope of entrusted affairs}

For a long time, the Chinese government has forbidden entrustment of the administrative compulsory measures. However, according to the feedback of corresponding administrative departments, it can be seen that the regulation has been inconsistent with China's current social situations. Many developed countries have defined the decision-making right of entrustment belongs to administrative subjects. They do so mainly to guarantee the administrative efficiency and administrative professionalism. Therefore, China should also put identification of entrustment into the scope of administrative subjects' discretionary power. This can provide vigorous support for administrative reforms, including delegation of power and streamlining administration. One thing to be noted is that China has not yet formed a mature administrative power classification system. Thus, listening of positive examples is not applicable to China. Many new administrative behaviors emerging in China have also restricted application of the method. According to Spain Public 
Administrative Organs and Shared Administrative Procedures and Netherlands Administrative Law General Rules both issued in 1992 and shown in Table 4, it can be found that there is a theoretical consensus between China and foreign countries, thinking that "the country should adhere to the principle of functional maintenance while entrusting individuals with the enforcement of public power”. Based on all the above discussed, this paper suggests that China's principal-agent theory should clearly forbid entrustment of the administrative standards making right and administrative organization right. Only in this way can uniqueness of the administrative field be better guaranteed.

Table 4. Legislations abroad

\begin{tabular}{cc}
\hline Laws & Content \\
\hline $\begin{array}{c}\text { Spain Public Administrative Organs and } \\
\text { Shared Administrative Procedures }\end{array}$ & $\begin{array}{c}\text { Article 13: “Administrative departments } \\
\text { can entrust its functions to the third parties as } \\
\text { long as the entrustment satiates technical, } \\
\text { economic, social, legal or regional factors.” }\end{array}$ \\
$\begin{array}{c}\text { Netherlands Administrative Law General } \\
\text { Rules }\end{array}$ & $\begin{array}{c}\text { Article 3: “Administrative departments can } \\
\text { entrust their functions excluding unless } \\
\text { elsewise stipulated or the nature of the power } \\
\text { is unsuitable for entrustment.” }\end{array}$ \\
\hline
\end{tabular}

\section{Conclusions}

To sum up, the principal-agent theory is feasible to be applied to China's administrative management. The strategies put forward in this paper, including provision of legal support, selection of entrusted subjects and clarification of entrustment affairs, have been verified in terms of their practical value. Therefore, this research can provide valuable reference for theoretical research and practice exploration in relevant fields.

\section{References}

[1] Robin Gauld. PRINCIPAL-AGENT THEORY AND ORGANISATIONAL CHANGE [J]. Policy Studies, 2007, 28(1):17-34.

[2] Posner E A. COST-BENEFIT ANALYSIS AS A SOLUTION TO A PRINCIPAL-AGENT PROBLEM [J]. Administrative Law Review, 2001, 53(1):289-297.

[3] Carlos Pestana Barros. Measuring efficiency in the hotel sector [J]. Annals of Tourism Research, 2005, 32(2):456-477. 